\title{
Effect of Work Environment and Work Loads on the Performance of Police Educators in Sepolwan Lemdiklat Polri
}

\author{
Abd. Manaf ${ }^{*}$, Matin $^{1}$, Siti Zulaikha ${ }^{1}$ \\ 1Department of Education Management, State University of Jakarta, Jakarta, Indonesia. \\ *Corresponding Author
}

How to Cite : Manaf, A., Matin, M., Zulaikha, S. (2019). Effect of Work Environment and Work Loads on the Performance of Police Educators in Sepolwan Lemdiklat Polri. International Journal for Educational and Vocational Studies, 1 (5), 461-466

\section{ARTICLE HISTORY}

Received: 15 June 2019

Revised: 21 July 2019

Accepted: 27 August 2019

KEYWORDS

Work environment;

Workload;

Work Performance;

\section{ABSTRACT}

The objective of this causal research was to obtain information concerning: (1) the effect of work environment toward work performance; (2) the effect of workload toward work performance; and (3) the effect of work environment toward workload. The research was conducted using a survey method with a path analysis testing hypothesis. This research, principals of teachers on Police Women School - Polri has been chosen as a unit analysis and 90 samples of principals were selected at random. The results of the research are as follows: (1) there is a direct positive effect of work environment toward work performance; (2) there is a direct negative effect of workload toward work performance; and (3) there is a direct negative effect of work environment toward workload.

\section{INTRODUCTION}

The Women's Police School as the Educational Institution of the Republic of Indonesia (RI) has the task of developing quality human resources in the field of Diktuk Bintara Polwan, Policewomen for Women and Children Services (PPA) and Negotiator Policewomen and various other training. In this regard, the Government of the Republic of Indonesia has developed a planned intervention to make educators consisting of lecturers, lecturers, civil servants, extraordinary teachers, tutors, and trainers at the National Police School Women's Education and Training Institute as the right choice for a career as a form community service.

A very decisive factor in the effort to improve the quality of human resources through education is educators (teachers, lecturers, trainers, and structures). Education is carried out in the order of how the quality of education and learning outcomes lies in how educators carry out their duties responsibly and refer to the basic values of life and the values of the educational process towards ideal conditions and benefit students, educators, and society. The description of the performance of educators is not perfect if it is not balanced with an explanation of the laws and regulations relating to performance. Therefore, the researcher presents several government policies related to the performance of educators.
First, the 1945 Constitution of the Republic of Indonesia Article 28 and 31: paragraph (1) has the right to develop themselves through fulfilling their basic needs, having the right to education and to benefit from science and technology, art and culture, to improve their quality of life and for the welfare of mankind. (2) every citizen has the right to education. It is implied that education is given to all communities with various layers without exception and does not discriminate. Education is one of the human rights in which the right to education contains economic, social, cultural, civil and political rights. The implementation of education to the full is a prerequisite for obtaining employment rights. Education taken by someone will make it easier for him to get a job.

Second, the educator's factor as implementing government policy in the form of curriculum. With the information contained in Law No. 20/2003 concerning the National Education System, the standard for educators has been set, namely, a professional who can carry out learning planning up to evaluating it. Perspectives on these policies need to be studied referring to Law No. 19/2005 Article 28 concerning National Education Standards which states that educators must have academic qualifications and competencies and have the ability to realize national education. Academic qualification is a minimum level that must be met by educators with the ownership of a diploma or certificate of 
relevant expertise. The academic qualifications are developed by BNSP and stipulated in Ministerial Regulations.

Third, Regulation of the Head of the Republic of Indonesia National Police No. 4/2010 Article 28 and 31 concerning the Indonesian National Police Education System relating to teaching staff, it is stated that educators are in charge of: a) planning, implementing and evaluating the learning process; b) conduct guidance, counseling and training; and c) conduct research in their fields. The ability of the educator is related to making POAC (Planning, Organizing, Actuating, and Controlling), namely his ability to carry out the learning process, and his ability to evaluate learning outcomes and the ability to develop students in actualizing the various potentials they have.

Police Education at the Women's Police School National Police Training Center aims to be able to give birth to students who in the end can become good servants of the state to protect the community. The National Police Sepolwan educators have a strategic role in giving birth to qualified young women police who can compete with the police force which has male and other armed forces. However, the strategic role will run optimally according to its function if the educators have high performance.

The high performance of educators is needed to improve the quality of teaching which has been declining. As expressed by the Chairperson of IPW, Neta Pane (2012) who stated that the education system in the Police School was very alarming. Tend to give birth to police cadres who are unprepared and lack intellectual. As a result, the police tend to compensate with arrogance and repression when dealing with the public. This is inseparable from the poor recruitment system and basic education of the Police in the country. Police cadres were only educated for three months at the State Police School (SPN). (Liputan 6, 2012). Three things must be applied in the education system of the Indonesian National Police, namely implementing free education at the National Police without levies, competent education, and certification. Thus, the performance of high educators is very much needed in the National Police Education and Training Center so that the quality of education is maintained and developed.

The empirical data that the researchers obtained at the National Police Education and Training Center is that there are 114 police educators. The researcher took a sample of 90 police educators including 30 respondents for the instrument trial. Then some problems were detected based on the SWOT analysis in the T.A Work Plan. 2019 National Police Education and Training Center Work Unit (2019), namely: a) lack of learning support facilities that affect the performance of educators; b) limited educational facilities in the form of small classrooms, inadequate learning chairs, computer laboratories, warehouse warehouses, caregivers, non-organic education transit rooms and alins / alongins in the form of computers for Polri administrative subjects and supporting information technology-based learning (e-learning); c) there are still educational staff Sepolwan who do not have experience in regional assignments, and d) lack of budget to support the implementation of education operations. Besides, there are also obstacles, namely the change in values in the community towards a consumptive lifestyle and if it is not addressed wisely it will have an impact on the decline in personnel performance (both educators and students), including high levels of social jealousy. (National Police Education and Training Institute Sepolwan, 2019).

The low performance of educators in Sepolwan is a big problem so efforts are needed to overcome them, including improving performance through improving factors that can affect performance improvement. Based on organizational theories, it is found that many factors are thought to influence performance. This study only focuses on performance problems which are limited to two variables, namely the work environment and workload (both are independent variables) and performance as the dependent variable.

From the Maharsi (2011) and Taufiq (2011) study, there are 10 teaching performance variables of educators which include: discipline in teaching attendance, timeliness in starting and ending lectures, attitudes / attitudes in lecture halls, intonation and volume in delivering lecture material, the role in encouraging student learning motivation for achievement, systematic in explaining lecture material, mastery of lecture material, suitability of lecture material with syllabus, actuality or relevance / application of lecture material, and familiarity and friendliness during the lecture process. (Maharsi and Taufiq, 2011).

Research conducted by Maharsi (2011) about the low performance of educators concluded that there are factors that are thought to hinder the teaching performance of educators, including: lack of financial compensation, inappropriate feedback/performance evaluation systems, distrust of educators towards leaders, unmotivated educators, improper recruitment, selection and placement decisions, lack of understanding of educators on stakeholders' desires, unclear teaching performance standards, inaccuracies in the implementation of quality standards, ineffective team/expertise groups (CBC) collaboration, ineffective Department and Center management, refusal of educators to change, ineffective communication and dissemination of information, planning activities that are not in accordance with needs, and lack of training/development for educators. (Maharsi, 2011).

\section{METHODS}

This research was carried out on police educators at Sepolwan Lemdiklat Polri. The time of the research activities was carried out from January 2019 to July 2019. The method used was a survey method with a path analysis 
approach to test the direct influence of the work environment and workload on performance. The population in this study were all police educators with 114 police educators with a sample of 60 respondents and a trial of 30 respondents not included in the sample. The validation of the research instrument used the Product Moment correlation formula where the questionnaire items were declared valid if $r$-count $\geq r$-table. The validity of this study uses r-critical $0.361(\mathrm{n}=60$, alpha 0.05). The analysis for calculating reliability uses the Cronbach Alpha formula, which compares between $r$ count with $r$-table score/value. The instrument was declared reliable when $r_{\text {count }}>r_{\text {table }}$ at the level of trust $\alpha=0.05$. Obtained the level of reliability of the instrument performance $r_{i t}=0.970$. $r_{i t}$ workload $=0.901$; and work environment $r_{i t}=0.935$. This study uses descriptive analysis and inferential analysis with the help of SPSS.

\section{RESULTS AND DISCUSSION}

Based on the

From the results of the calculation of path analysis, the direct effect of the work environment on performance, the path coefficient value is equal to 0.463 and the value of the $t_{\text {count }}$ coefficient is 0.571 . The $t_{\text {table }}$ coefficient value for $\alpha=0.05$ is 2.66. The meaning of this path coefficient is significant. This finding can be interpreted that the work environment has a direct positive effect on performance. In other words, if the work environment is improved and improved, it will result in increased performance.

The research findings are in line with Robbins's statement (2015: 307): The work environment allows employees to carry out teaching tasks better. This will encourage educators to provide quality services to students. This finding is also in line with the results of research by Ida Putra and Cokorda Jayanta (2012: 25): the direct influence of the work environment on the performance that is fully supported by the work environment. Physical and non-physical work environments will be very important to performance.

If police educators can participate responsibly in carrying out teaching tasks and training, expressing thoughts, and fulfilling and developing potential, then they will tend to identify themselves and give good outcomes. There is a positive correlation between the work environment and performance. This can be seen in Sepolwan, which shows that police educator who have a good working environment will have high performance because they feel the achievement of organizational goals will be easier to reach if the work is carried out supported by a good working atmosphere.

From the results of the calculation of path analysis, the direct effect of Workload on Performance, the path coefficient value is -0.316 and the value of the $t_{\text {count }}$ coefficient is -0.473 . The table coefficient value for $\alpha=0.01$ is -2.66 . This finding can be interpreted that the workload has a direct negative effect on performance. In other words, an increase in workload will be followed by a decrease in performance.

Heavy workload influences performance. The results of this study are also consistent with the research of Fernando Tjiabrata, Bobe Lumanaw and Lucky Dotulung (2015: 40): workload has a significant influence in the context of performance. In line with the research of Jeky Rolos, Sofia Sambul and W. Rumawas (2017: 17) which also states the workload has a direct influence on performance.

The workload is closely related to psychology and the ability and ability of an employee to carry out the work assigned to him. Workloads that can be completed with normal time in a certain time unit will provide good quality work. His ability to complete his tasks must be following the talent possessed by an employee. If the employer mistakenly gives the task load under the capacity of a subordinate, the quality of work of the subordinates will not be in line with expectations.

From the results of the calculation of path analysis, the direct effect of the work environment on workloads, the path coefficient value is $-0,339$ and the tcount coefficient value is $-0,339$. The ttable coefficient value for $a=0.05$ is -2.66 . The meaning of this path coefficient is significant. This finding can be interpreted that the work environment has a direct negative effect on workload. In other words, an increase in the work environment results in a decrease in workload.

The results of these studies are under Mukhlis Hidayatullah and Henny's (2009: 01) study which states that the work environment has a direct influence on workload. The physical work environment affects the workload felt by employees.

The workload is closely related to psychology and the ability and ability of an employee to carry out the work assigned to him. Workloads that can be completed with normal time in a certain time unit will provide good quality work. His ability to complete his tasks must be following the talent possessed by an employee. If the employer mistakenly gives the task load under the capacity of a subordinate, the quality of work of the subordinates will not be in line with expectations.

The condition of a good work environment in the workplace will make employees feel comfortable in carrying out their duties. Convenience can have an impact on reducing workload and increasing employee performance, but on the other hand, the discomfort of the work environment experienced by employees can result in a decrease in workload and employee performance. The three hypotheses are summarized in the following table:

Table 1. Summary of Hypothesis Testing Results

\begin{tabular}{|c|c|c|c|c|c|}
\hline \multirow[b]{2}{*}{ Hypothesis } & \multirow{2}{*}{$\begin{array}{l}\text { Statistical } \\
\text { Hypothesis }\end{array}$} & \multicolumn{2}{|c|}{ Statistic Test } & \multirow[b]{2}{*}{ Decision } & \multirow{2}{*}{$\begin{array}{c}\text { Conclusic } \\
n\end{array}$} \\
\hline & & $t_{\text {count }}$ & $\begin{array}{l}\text { table } \\
a=0,01\end{array}$ & & \\
\hline $\begin{array}{c}\text { Work } \\
\text { Environment }\end{array}$ & $H_{0}: \beta_{31} \geq 0$ & $3,46^{* *}$ & 2,66 & $\mathrm{H}_{0}$ & $\begin{array}{l}\text { Direct } \\
\text { positive }\end{array}$ \\
\hline
\end{tabular}




\begin{tabular}{|c|c|c|c|c|c|}
\hline $\begin{array}{l}\text { has a direct } \\
\text { positive } \\
\text { effect on } \\
\text { Performance }\end{array}$ & $\mathrm{H}_{1}: \beta_{31}<0$ & & & rejected & effect \\
\hline $\begin{array}{l}\text { Workload } \\
\text { has a } \\
\text { negative } \\
\text { direct effect } \\
\text { on } \\
\text { Performance }\end{array}$ & $\begin{array}{l}H_{0}: \beta_{32} \leq 0 \\
H_{1}: \beta_{32}>0\end{array}$ & $-2,93^{* *}$ & $-2,66$ & $\begin{array}{c}\mathrm{H}_{0} \\
\text { rejected }\end{array}$ & $\begin{array}{c}\text { Direct } \\
\text { negative } \\
\text { effect }\end{array}$ \\
\hline $\begin{array}{l}\text { Work } \\
\text { Environment } \\
\text { has a direct } \\
\text { negative } \\
\text { effect on } \\
\text { Workload }\end{array}$ & $\begin{array}{l}H_{0}: \beta_{21} \leq 0 \\
H_{1}: \beta_{21}>0\end{array}$ & $-2,74^{* *}$ & $-2,66$ & $\begin{array}{c}\mathrm{H}_{0} \\
\text { rejected }\end{array}$ & $\begin{array}{c}\text { Direct } \\
\text { negative } \\
\text { effect }\end{array}$ \\
\hline
\end{tabular}

\section{CONCLUSION}

1. Improvement and improvement of the work environment in carrying out its roles and functions will lead to increased performance of police educators at the National Police Training Center. Based on the results of the calculation of the path coefficient obtained by the direct effect of the work environment on performance py $1=0.463$. While the value of $t_{\text {count }}=4.30$; while the value of $t_{\text {table }}$ at the significance level a $(0.01)=2.66$. Therefore, the value of $t$ count $>t$ table, then $\mathrm{H} 0$ is rejected, $\mathrm{H} 1$ is accepted. Thus it can be concluded that the work environment has a direct positive effect on performance.

2. A high workload will reduce the performance of police educators in Sepolwan. Based on the results of the calculation of the path coefficient obtained by the direct effect of workload on the performance py2 $=-0.316$. While the value of $t_{\text {count }}=-2.93$; while the table value at the level of significance a $(0.01)=-2.66$; because the value of the $t_{\text {count }}$ coefficient is smaller than the $t_{\text {table }}$ coefficient, then $\mathrm{H} 0$ is rejected, $\mathrm{H} 1$ is accepted. Thus it can be concluded that workload has a direct negative effect on performance.

3. Improvement and improvement of the work environment have caused a decrease in workload for educators in Sepolwan Lemdiklat Polri. Based on the results of the calculation of path coefficients obtained by the direct effect of the work environment on the workload $\rho y 3=-0,339$. While the value of $t_{\text {count }}=-2.74$; while the $t_{\text {table }}$ value at the significance level $\alpha=0.01=$ $1.97 \alpha=-2.66$. Because the value of the $t_{\text {count }}$ coefficient is smaller than the table coefficient, then $\mathrm{H} 0$ is rejected, $\mathrm{H} 1$ is accepted. Thus it can be concluded that the work environment has a direct negative effect on workload.

\section{Suggestion}

1. The leadership encourages the improvement of the cohesiveness of police educators in the context of creating a dynamic work environment between peer educators to carry out special tasks in groups. If a comfortable work environment is created, the results achieved will be better.

2. Educators are friendly with each other both among colleagues and among school members including students so that a harmonious working atmosphere will be created.

3. Not getting used to delaying teaching assignments so that the workload for teaching tasks in the future does not feel heavy.

4. Educators must provide Teaching Draft or Enrichment to Leaders and students as material guidance during teaching.

5. Fun in teaching needs to be applied so that students do not feel monotonous during the learning process.

6. Educators are trained to be mentors for students. Following the main tasks of the teaching staff, namely teaching, educating, training, guiding, evaluating, and directing, it becomes commonplace if the educator is called a mentor.

7. The leadership provides a variety of teaching aids so that the learning process can run more effectively and efficiently;

8. The leadership and police educators enthusiastically innovate to create a modern learning atmosphere by mastering the use of the latest technological tools.

9. The leadership guides police educators so that they are always eager to pursue higher education in line with their scientific fields.

10. Police educators sincerely work for the progress of students as the nation's successor who will continue the country's struggle. So, a comfortable work environment is jointly improved because it will ease the heavy workload.

11. Educators mingle with various layers of society to provide awareness of the meaning of education for servants of the state in Sepolwan Polri especially those who not only teach police education alone but also educate in general that is related to behavior and dedication to the nation and state.

\section{REFERENCES}

Andre, Rae. (2008). Organizational Behavior: An Introduction to Your Life in Organizations. New Jersey: Pearson Education.

Anoraga, Pandji., dan Widiyanti, Ninik. (2013). Dinamika Koperasi. Jakarta: Rineka Cipta.

Colquitt, Jason., Lepine, Jefferey, dan Wesson, Michael. (2013). Organizational Behavior: Improving 
Performance and Commitment in the Workplace. New York: McGraw-Hill.

Daft, Richard. (2008). Management. USA: Thomson South-Western.

Dhania, Rama. (2010). Buku Ajar Manajemen Sumber Daya Manusia. Surabaya: Univ. Wijaya Putra.

Dondokambey, Zaneta., Saerang, David., dan Pandowo, Merinda. (2018). Pengaruh Beban Kerja dan Lingkungan Kerja terhadap Burnout.

Ganster, dan Rosen. 2013. Workload on Management of Human Resource. Singapore: Person Prentice Hal.

Gibson, James., Ivancevich, Ivancevich, M dan Konopaske, Robert. (2009). Organization: Behavior, Structure, Processes. New York: McGraw-Hill.

Haynes, Jeffrey. (2008). Development Studies. UK: Polity Press.

Heizer, Jay. (2001). Operations Management: Statistical Tools for Managers. Singapore: Prentice Hall.

Jex, Steve. (2012). Organizational Psychology: A Scientist - Practitioner Approach. New York: John Wiley \& Sons, Inc.

Kurnia, Rahmat. (2010). Smart Way to Get a Job. Elexmedia Komputindo. Jakarta: PT. Gramedia.

Luthans, Fred. (2011). Organizational Behavior: An Evidences-Based Approach.New York: McGraw-Hill.

Mangkunegara, Anwar Prabu. (2009). Manajemen Sumber Daya Manusia Perusahaan. Remaja Rosdakarya.

Mullins. (2006). Essential of Organisational Behaviour. England, Prentice Hall.

Nitisemito, Alex Soemadji. (2000). Wawasan Studi Kelayakan dan Evaluasi Proyek. Yogyakarta: Bumi Aksara.

Peraturan Kepala Kepolisian Negara RI No. 4/ 2010 tentang Sistem Pendidikan Kepolisian Negara RI.

Rachmawati, Tutik., dan Daryanto. (2013). Penilaian Profesi Kinerja Tenaga Pendidik dan Angka Kreditnya. Yogyakarta: Gaya Mediva.

Wijaya, John Henry. Sustainable Business Practice. (2017). Bandung: Widyatama.

Adityawarman, Yudha., Salim, Bunasor., dan Sinaga, Bonar. Pengaruh Beban Kerja terhadap Kinerja Karyawan PT. BRI, Tbk Cabang Krekot.

Boimau, Serlyansie. Evaluasi Kinerja Dosen ditinjau dari Prestasi Belajar Mahasiswa di Jurusan Kebidanan Politeknik Kesehatan Kemenkes Kupang Tahun 2013.

Boose, Nikson., Rumawas, Wehelmina., dan Tumbel, Tinneke. Pengaruh Lingkungan Kerja terhadap Kinerja Karyawan pada PT. Perusahaan Ekspedisi Maumbi Kota Manado.

Dondokambey, Zaneta., Saerang, David., dan Pandowo, Merinda. (2018).Pengaruh Beban Kerja dan
Lingkungan Kerja terhadap Burnout. Jurnal EMBA.ISSN 2303-1174.

Harini, Sri., Sudarijati., dan Kartiwi, Niken. (2018). Workload, Work Environment and Employee Performance of Housekeeping. International Journal of Latest Engineering and Management Research (IJLEMR) ISSN: 2455-4847. IJLEMR.

Hossein, Sajjad. (2016). Teaching Workload and Performance: An Empirical Analysis on Some Selected Private Universities of Bangladesh. International Journal of English and Education.ISSN: 2278-4012. Research Gate.

Irawati, Rusda., dan Carollina, Dini. (2011). Analisis Pengaruh Beban Kerja terhadap Kinerja Karyawan Operator pada PT. Giken Precision Indonesia.

Maharsi, Petrus. Upaya Peningkatan Kinerja Dosen di Indonesia Masih Terkendala Minimnya Kompensasi (Studi Kasus Politeknik Semarang, Bandung dan Jakarta). Jurnal Pengembangan Humaniora.

Monica, Tjio., dan Anggela, Melyana. Analisis Pengaruh Lingkungan Kerja terhadap Kinerja Karyawan Melalui Kepuasan Kerja di Hotel X di Surabaya.

Putra, Fariz., Utami, Hamidah., dan Hakam, Muhammad. Pengaruh Lingkungan Kerja terhadap Kinerja (Studi pada Karyawan PT. Naraya Telematika Malang).

Putra, Ida Bagus Udayana., dan Jayanta, Cokorda Bagus. Peranan Beban Kerja dan Lingkungan Kerja Non Fisik terhadap Kinerja Karyawan pada The Mansion Resort Hotel \& Spa.,

DOI://doi.org/10.5281/zenodo.1492943.

Rolos, Jeky., Sambul, Sofia., dan Rumawas, Wehelmina. (2018). Pengaruh Beban Kerja terhadap Kinerja Karyawan pada PT. Asuransi Jiwasraya Cabang Manado Kota. Jurnal Administrasi Bisnis. ISSN: 2338-9605.

Tjiabrata, Fernando., Lumanaw, Bude., dan Dotulung, Lucky. (2017). Pengaruh Beban Kerja dan Lingkungan Kerja terhadap Kinerja Karyawan PT. Sabar Ganda Manado. Jurnal EMBA. ISSN 2303-1174.

Samson, Gitachi., dan Waiganjo, Maina. (2015). Effect of Workplace Environment on the Performance of Commercial Banks Employees in Nakuru Town. International Journal of Managerial Studies and Research (IJMSR) Volume 3, Issue 12, December 2015, PP 76-89 ISSN 2349-0330. IJMSR.

Shah, Syed Saad Hussain. Et al. (2011). Workload and Performance of Employees. Interdisciplinary Journal of Contemporary Research in Business. Ijcrb.

Sutoyo. Pengaruh Beban Kerja, Lingkungan Kerja dan Motivasi terhadap Kinerja Pegawai pada Dinas Bina Marga Propinsi Sulawesi Tengah.

Taufiq, Rohmat. (2011). Penilaian Kinerja Dosen dalam Bidang Belajar Mengajar di Fakultas Teknik 
Universitas Muhammadiyah Tangerang. Factor Exacta. ISSN 1979276X.

Wijaya, Hendry. (2017). Pengaruh Lingkungan Kerja terhadap Kinerja Pegawai pada Instansi Pemda Kabupaten Musi Banyuasin (Studi Kasus Dinas Pertambangan dan Energi Kabupaten Musi Banyuasin). ISSN: 2540-816X. 